Glamočlija, M. M., Popović, V., Janković, S., Glamočlija, Đ., Čurović, M., Radović M., Đokić, M. (2020): Nutrition effect to productivity of bioenergy crop miscanthus $x$ giganteus in different environments. Agriculture and Forestry, 66 (2): 67-77.

DOI: 10.17707/AgricultForest.66.2.07

\begin{abstract}
Milena MLADENOVIĆ GLAMOČLIJA ${ }^{1}$, Vera POPOVIĆ ${ }^{2 *}$, Snežana JANKOVIĆl, Đorđe GLAMOČLIJA ${ }^{3}$, Milić ČUROVIĆ Marko RADOVIĆ ${ }^{5}$ and Milorad ĐOKIĆ ${ }^{6}$
\end{abstract}

\title{
NUTRITION EFFECT TO PRODUCTIVITY OF BIOENERGY CROP MISCANTHUS X GIGANTEUS IN DIFFERENT ENVIRONMENTS
}

\begin{abstract}
SUMMARY
Miscanthus x giganteus Greef et Deu is a perennial C4 grass, originally from East Asia. Morphological productive characteristics of miscanthus were analyzed in this study: plant height in the tasseling period, number of leaves on stalk in the tasseling period, number of stalk in tiller, number of stalk with tassel, dry plant yields, stalk moisture in harvest time and cellulose content. The miscanthus achieves high yields and excellent performance in summer drought conditions because it has a well-developed root system. In the period AprilOctober 2018-2019 there was less precipitation (428 $\mathrm{mm}$ and $431 \mathrm{~mm}$ ) than the optimal needs of the plants $(550 \mathrm{~mm})$. In the two-year average the miscanthus had a stalk height of $342.4 \mathrm{~cm}$ and achieved a yield of $31.4 \mathrm{t} \mathrm{ha}^{-1}$. To these morphologically productive traits significantly affected weather conditions, nitrogen nutrients as well as the interaction of the factors studied.
\end{abstract}

Keywords: Miscanthus, nitrogen top dressing, morphological and productive traits, environments

\section{INTRODUCTION}

Miscanthus x giganteus Greef et Deu is a perennial C4 grass, originally from East Asia. It has high production potential and is ecologically very acceptable species suitable for the production of solid biofuels (Živanović et al, 2014; Đurić et al., 2019). Generates high biomass yield, in the period to 20 years, has good energy performance and relatively low investment in production (Acikel, 2011). Miscanthus (or Elephant Grass) is a popular choice for biofuel production, because it produces a crop every year without the need for replanting

\footnotetext{
${ }^{1}$ Milena Mladenović Glamočlija (corresponding author: milena.m.glamoclija@gmail.com), Snežana Janković, IPN Institute of Applied Sciences, Belgrade, SERBIA;

${ }^{2}$ Vera Popović, Institute of Field and Vegetable Crops, Maksima Gorkog 30, Novi Sad, SERBIA;

${ }^{3}$ Đorđe Glamočlija, University of Belgrade, Faculty of Agriculture, Zemun-Belgrade, SERBIA;

${ }^{4}$ Milić Čurović, University of Montenegro, Biotechnical Faculty, Podgorica, MONTENEGRO;

${ }^{5}$ Marko Radović, BioSens Institute, Dr Zorana Djindjica 1, Novi Sad, SERBIA;

${ }^{6}$ Milorad Đokić, University of Megatrend, Faculty of Biofarming, BačkaTopola, SERBIA;

Paper presented at the GEA (Geo Eco-Eco Agro) International Conference 2020, Podgorica.

Notes: The authors declare that they have no conflicts of interest. Authorship Form signed online.

Received:01/04/2020

Accepted:12/06/2020
} 
and due to the rapid growth, low mineral content, and high biomass yield, outperforming maize and other alternatives. It is an excellent choice for our environment, our economy, and our future security of energy supply. It also complements forestry as it sits easily alongside to help even out supply chain needs.During the multi-year life cycle, miscanthus develops a strong deep root system of high suction power and the plants are tolerant to less favorable agroecological conditions. However, the highest biomass yield is obtained only under conditions of favorable water regime $(550 \mathrm{~mm}$ of precipitation during the vegetation cycle) as stated by Clifton-Brown et al. (2002).

This study has shown that summer precipitation amounts are the most important for achieving high and stable yields. This has been confirmed by other researchers, for example Mont and Zatta (2009); Dželetović et al. (2013); Ikanović et al. (2015) and others. In the year of the most favorable water regime and monthly rainfall, a significant yield of dry stalks, $31,533 \mathrm{~kg} \mathrm{ha}^{-1}$, was obtained. In the year of the most favorable water regime and monthly schedule precipitation was obtained a significant yield of dry stalks, $31,533 \mathrm{~kg} \mathrm{ha}^{-1}$.

By studying the properties of miscanthus production in the environmental conditions of Northern Europe, Lewandowski and Heinz (2003) have concluded that favorable water and air temperature regimes have the largest effect on biomass yield. In the aforementioned research, nitrogen opdressing had a significant influence in the first year and in two-year average. Overall, nitrogen topdressing increased dry stalks yield by $5 \%$.

The aim of this research was the study of the influence of the environment and nutrition, i.e. nitrogen top dressing and the on the morphological and production properties. The aim of this study was to investigate the influence of the environment and nutrition, i.e. nitrogen top dressing on the morphological and production properties of determine the impact of nitrogen top dressing of crops on miscanthus production in divergent years, influence of the environment and nutrition on the morphological and production properties.

\section{MATERIAL AND METHODS}

The subject of the research is mischantus, a clone imported from Germany for introduction to energy crops production. The experiment was performed in Surduk (Serbia), on chernozem soil type. At the beginning of the research the crop was seven years old, and was in years to achieve maximum yield for commercial production. In the period 2018-2019 two variants were tested control (no nitrogen topdressing), and variant with $30 \mathrm{~kg} \mathrm{ha}^{-1}$ nitrogen top dressing, Due to well-developed root system, even in summer drought conditions, miscanthus gives high yields and excellent performance on fertile soils with good physical qualities. In the period April-October 2018-2019 there was less precipitation $(428 \mathrm{~mm}$ and $431 \mathrm{~mm}$ ) compared to the optimal needs of the plants $(550 \mathrm{~mm})$. In the two-year average the miscanthus had a stalk height of $342.4 \mathrm{~cm}$ and achieved a yield of $31.4 \mathrm{t} \mathrm{ha}^{-1}$. These morphological and productive traits 
were significantly affected by weather conditions (higher amounts of summer precipitation), nitrogen nutrients, as well as, the interaction of the studied factors.

Data Analysis

The analysis of the experimental data was performed by descriptive and analytical statistics using the statistical package STATISTICA for Windows 12. Testing the significance of the differences between the calculated mean values of the examined factors (years and variant of fertilizing) was performed by using a two-factor model of variance analysis. All significance ratings were based on the F-test and LSD-test for significance level of $0.05 \%$ and $0.01 \%$. The relative dependence was determined by the method of correlation analysis (Pearson's correlation coefficients), and the obtained coefficients tested by t-test for significance level $0.05 \%$ and $0.01 \%$.

\section{RESULTS AND DISCUSSION}

Meteorological conditions: During the period March-October there was $428 \mathrm{~mm}$ of precipitation in the first year (2018), and $431 \mathrm{~mm}$ in the second year of the experiment (2019). The differences in the amount of rainfall per year were small, but in 2019 amount of rainfall was evenly distributed in stages of plant growth. Thermal conditions were more favorable in 2019. During the summer there were high air temperatures, but it was a period with large precipitation amounts, Table 1.

Table 1. Total precipitation sums ( $\mathrm{mm})$ and average temperatures $\left({ }^{\circ} \mathrm{C}\right)$ in the tested period, 2018-2019

\begin{tabular}{|c|c|c|c|c|c|c|c|c|c|c|c|l|l|l|}
\hline Parameters & I & II & III & IV & V & VI & VII & VIII & IX & X & XI & XII & $4-9$ & Year \\
\hline \multicolumn{10}{|c|}{ Total precipitation sums (mm) } \\
\hline 2018 & 39 & 47 & 58 & 35 & 81 & 85 & 97 & 77 & 53 & 37 & 49 & 65 & 428 & 723 \\
\hline 2019 & 22 & 34 & 12 & 77 & 142 & 89 & 43 & 40 & 28 & 14 & 54 & 55 & 431 & 610 \\
\hline Average & 55 & 15 & 54 & 52 & 80 & 82 & 65 & 56 & 54 & 54 & 52 & 45 & 497 & 692 \\
\hline Optimum & - & - & 50 & 55 & 85 & 90 & 100 & 80 & 55 & 35 & - & - & 550 & - \\
\hline \multicolumn{10}{|c|}{ Mean temperatures $\left(^{\circ}\right.$ C) in tested period } & & \\
\hline 2018 & 3 & 2 & 5 & 17 & 20 & 21 & 22 & 24 & 18 & 14 & 8 & 3 & 17.6 & 12,9 \\
\hline 2019 & 2 & 6 & 11 & 14 & 16 & 24 & 24 & 26 & 20 & 16 & 12 & 6 & 19.3 & 14,8 \\
\hline Average & 1.6 & 2.1 & 6.9 & 13 & 18 & 22 & 24 & 24 & 19 & 11 & 7.1 & 2.4 & 17.2 & 13,1 \\
\hline Optimum & - & - & 10 & 15 & 18 & 19 & 21 & 21 & 18 & 10 & - & - & 16,5 & - \\
\hline
\end{tabular}

Lewandowski et al. (2000) and Clifton-Brown et al. (2002) suggest that the optimal amount of precipitation for miscanthus during the annual plant growth, for the geographical area of Western Europe, is around $550 \mathrm{~mm}$.

By studying the relationship between plant growth and meteorological conditions, Lewandowski and Heinz (2003) and Maksimovic et al. (2016 a, b) concluded that higher air temperatures during summer, with abundant precipitations, have a very favorable effect on the intense stalks growth and photosynthesis processes. 
Table 2. Productive characteristics of miscanthus, 2018-2019

\begin{tabular}{|c|c|c|c|c|c|c|}
\hline \multirow{2}{*}{ Variant } & \multicolumn{2}{|c|}{ Year } & \multirow{2}{*}{ Average } & \multirow{2}{*}{ No } & \multirow{2}{*}{$\begin{array}{l}\text { Std. } \\
\text { Dev. }\end{array}$} & \multirow{2}{*}{ Std. Err } \\
\hline & 2018.* & 2019. & & & & \\
\hline \multicolumn{7}{|c|}{ Stalk height in the tasseling period $-\mathrm{SHT}, \mathrm{cm}$} \\
\hline Control & 328.5 & 356.25 & 342.5 & 8 & 16.5 & 3.7 \\
\hline N $30 \mathrm{~kg} \mathrm{ha}^{-1}$ & 356.3 & 360.5 & 358.4 & 8 & 7.2 & 6.1 \\
\hline Average & 342.4 & 358.5 & 350.44 & 16 & 14.8 & \\
\hline \multicolumn{7}{|c|}{ Number of leaves on stalk in the tasseling period, $\mathrm{NoL}$} \\
\hline Control & 15.0 & 16.3 & 15.6 & 8 & 1.4 & 0.5 \\
\hline N $30 \mathrm{~kg} \mathrm{ha}^{-1}$ & 17.3 & 17.3 & 17.3 & 8 & 0.9 & 0.3 \\
\hline Average & 16.1 & 16.8 & 16.4 & 16 & 1.4 & 0.4 \\
\hline \multicolumn{7}{|c|}{ Number of stalks in tassel,NoST } \\
\hline Control & 15.50 & 21.00 & 18.50 & 8 & 3.42 & 1.21 \\
\hline N $30 \mathrm{~kg} \mathrm{ha}^{-1}$ & 21.50 & 25.25 & 23.13 & 8 & 2.69 & 0.95 \\
\hline Average & 18.25 & 23.13 & 20.82 & 16 & 3.82 & 0.95 \\
\hline \multicolumn{7}{|c|}{ Number of stalks in tiller, NoSTL } \\
\hline Control & 27.75 & 27.50 & 27.63 & 8 & 1.92 & 0.68 \\
\hline N $30 \mathrm{~kg} \mathrm{ha}^{-1}$ & 30.75 & 31.75 & 31.25 & 8 & 1.91 & 0.67 \\
\hline Average & 29.25 & 29.63 & 29.44 & 16 & 2.63 & 0.66 \\
\hline \multicolumn{7}{|c|}{ Dry stalks yield - DSY, $\mathrm{kg} \mathrm{ha}^{-1}$} \\
\hline Kontrola / Control & 30.655 & 33.373 & 32.014 & 8 & 1614.54 & 570.83 \\
\hline $\mathrm{N} 30 \mathrm{~kg} \mathrm{ha}^{-1}$ & 32.210 & 34.525 & 33.367 & 8 & 1702.65 & 601.97 \\
\hline Prosek / Average & 31.432 & 33.948 & 32.690 & 16 & 1748.73 & 437.18 \\
\hline \multicolumn{7}{|c|}{ Stalk moisture in harvest time - SMHT, $\%$} \\
\hline Control & 8.55 & 8.09 & 8.32 & 8 & 0.45 & 0.16 \\
\hline N $30 \mathrm{~kg} \mathrm{ha}^{-1}$ & 8.58 & 8.20 & 8.39 & 8 & 0.27 & 0.09 \\
\hline Average & 8.57 & 8.15 & 8.36 & 16 & 0.36 & 0.09 \\
\hline \multicolumn{7}{|c|}{ Cellulose content, CC, $\%$} \\
\hline Control & 32.07 & 32.15 & 32.113 & 8 & 0.05 & 0.02 \\
\hline $\mathrm{N} 30 \mathrm{~kg} \mathrm{ha}^{-1}$ & 32.03 & 32.18 & 32.105 & 8 & 0.08 & 0.03 \\
\hline Average & 32.05 & 32.17 & 32.108 & 16 & 0.06 & 0.02 \\
\hline
\end{tabular}

\begin{tabular}{|c|c|c|c|c|c|c|}
\hline Parameter & \multicolumn{2}{|c|}{ Year } & \multicolumn{2}{c|}{ Variant } & \multicolumn{2}{c|}{ Year x Variant } \\
\hline LSD & 0.05 & 0.01 & 0.05 & 0.01 & 0.05 & 0.01 \\
\hline SHT & 8.225 & 11.637 & 8.225 & 11.637 & 11.632 & 16.457 \\
\hline NoL & 1.285 & 1.818 & 1.285 & 1.818 & 1.817 & 2.571 \\
\hline NoST & 2.237 & 3.165 & 2.237 & 3.165 & 3.162 & 4.476 \\
\hline NoSTL & 1.586 & 2.244 & 1.586 & 2.244 & 2.243 & 3.173 \\
\hline DPY & 1151.714 & 1629.378 & 1151.714 & 1629.378 & 1628.769 & 2304.289 \\
\hline SMHT & 0.018 & 0.025 & 0.018 & 0.025 & 0.026 & 0.036 \\
\hline CC & 0.355 & 0.503 & 0.355 & 0.803 & 0.503 & 0.711 \\
\hline
\end{tabular}


Stalk height in the tasseling period - SHT

In the two-year average, miscanthus formed stalks that were $342.4 \mathrm{~cm}$ high in the tasseling period. This morphological trait was significantly influenced by both studied factors, weather conditions and nitrogen nutrients (Table 2).

In 2019 the plants had higher stalks compared to 2018. These values in the overall average were higher in 2019 by $16.1 \mathrm{~cm}$ or $4.7 \%$. In control the difference by years was $27.75 \mathrm{~cm}(8.45 \%)$, and in the variant with nitrogen fertilization were $4.2 \mathrm{~cm}(1.18 \%)$, Figure 1a.

Number of leaves on stalk in the tasseling period, NoL

The average number of leaves in the tasseling phase of miscanthus was 16.1. This morphological trait was statistically significantly influenced by both of studied factors, weather conditions and nitrogen nutrients (Table 2).

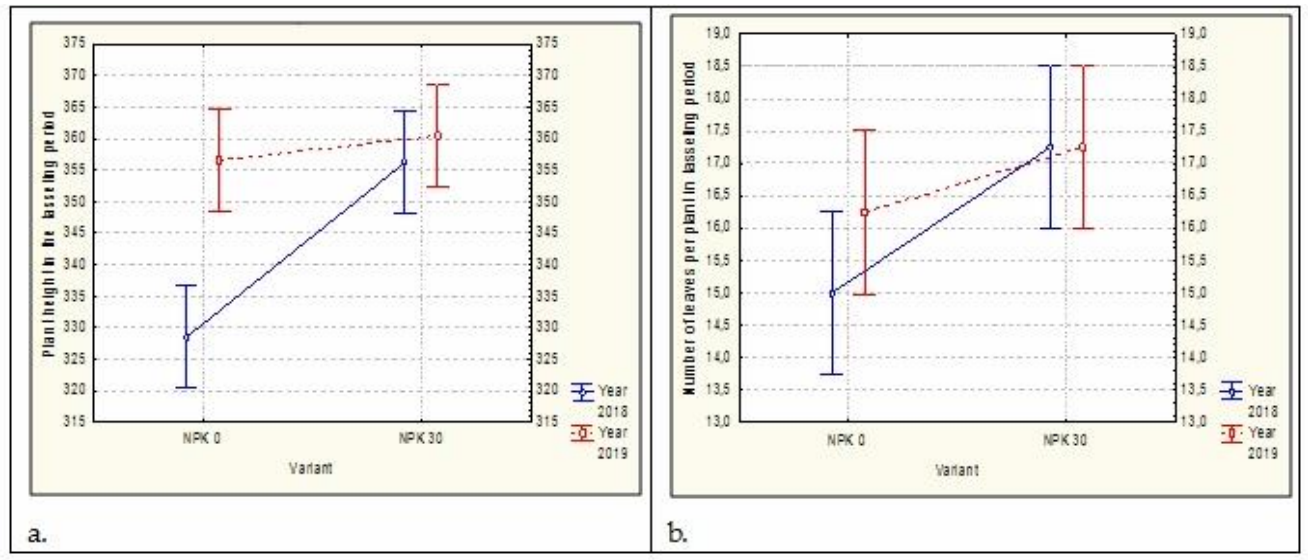

Figure 1. Effect of nutrition of plant height (cm, a.) And number of leaves per plant (b.), 2018-2019

A more favorable year for leaf development was 2019 and plants had statistically significantly more leaves compared to 2018. This difference was $8.7 \%$ in control and $4.34 \%$ on average for both factors, respectively. Plants in the variant with nitrogen had about $10 \%$ more leaves on the stalk, Tables 2, Figure 1b.

\section{Number of stalks in tassel period, NoST}

In the two-year average, the number of stalks in the miscanthus tassel period was 18.50 in control, and 23.13 in the variant with nitrogen fertilization. The influence of both factors on tasseling intensity was statistically significant (Table 2). More favorable weather (precipitations and temperatures) conditions influenced the plants to form more secondary stalks in 2018.In the control variant number of stalks in tasseling period, in 2019 , was by 5.50 (by $35.48 \%$ ) higher as compared to 2018. Similarly, number of stalks in the variant with nitrogen fertilization in 2019 was by 3.75 (by 7.44\%) higher than in 2018.Consequently, more stalks in the tassel period were formed on average, for both variants, in 2019 than in 2018, i.e. by were 4.88 (by 26.47\%), (Table 2, Figure 2a). 
Number of stalks in tiller period, NoSTL

The average number of shoots for both years was 29 in the tiller period of miscanthus. In control variant there were 27.63 shoots developed, and in the variant with nitrogen fertilization 31.25 (Table 2, Figure 2b).

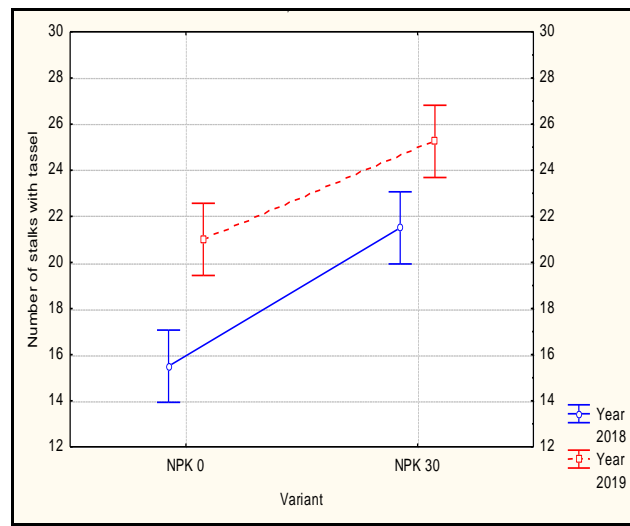

a.

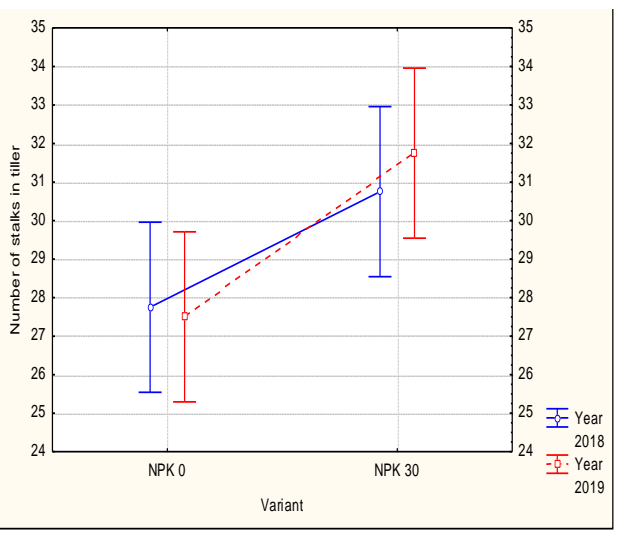

b.

Figure 2. Effect of nutrition of number of stalks of tassel (a.) and number of stalks in tiller (b.), 2018-2019

Meteorological conditions and nitrogen fertilization had little effect on the number of shoots in the tiller. Therefore, there were no statistically significant variations between examined variants in the 2-year average (Table 2, Figure $2 b$ ). The year 2019 was more favorable for NoSTL and the plants formed 31.75 shoots in the nitrogen fertilization variant. This value was higher by $2.3 \%$ than in 2018 , which was statistically significant.

Stalk moisture at the harvest time, SMHT

The average moisture content at the harvest time, for both years, was $8.36 \%$. The stalks had higher moisture content in 2018. The largest difference in the moisture content was $0.42 \%$. On the other hand, the individual variations were small and did not have a significant effect on the total moisture content of stalks (Dželetović et al., 2009), Table 2.

Dry stalks yield, DSY

The average yield of dry miscanthus stalks, for both studied years, was $32.02 \mathrm{~kg} \mathrm{ha}^{-1}$ in the control and $33.37 \mathrm{~kg} \mathrm{ha}^{-1}$ in the nitrogen top dressing variant. Biomass yield was statistically significantly influenced by both studied factors, weather conditions and top dressing (Table 2). Weather conditions in 2019 were more favorable for the formation of stalks, although there was less precipitation in the growing season. Therefore, dry stalks' yield in 2019 was higher by 2,718 $\mathrm{kg} \mathrm{ha}^{-1}$ (by $8.86 \%$ ) in control and by $2,315 \mathrm{~kg} \mathrm{ha}^{-1}$ (by $7.19 \%$ ) in the variant with nitrogen top dressing, as compared to 2018. On average, dry stalk yield was by $8.01 \%$ higher in 2019 compared to 2018 . There were also statistically significant variations between individual treatments (Table 2, Figure 3a). The impact of meteorological conditions and nitrogen fertilizers on the yield of stalks was 
significant, which was also found in the research by Gonzalez-Dugo et al. (2010); Dželetović et al. (2013); Dželetović and Glamočlija (2015); Glamočlija et al. (2018) and Đurić et al. (2019).



Figure 3. Effect of nutrition of dry yield per plant (a.) and cellulose content (b.),

\section{Cellulose content, $C C$}

2018-2019

Carbohydrates make up about $80 \%$ of the air-dry mass of the miscanthus stalks, while the cellulose content is $30-35 \%$. According to the results reported by Lewandowski and Heinz (2003); Zivanovic et al. (2014); Djuric and Glamoclija (2017) and other authors, the meteorological conditions and applied agrotechnical practices do not have a statistically significant effect on the chemical composition of above-ground biomass and also on the content of cellulose in stalks.

Studying the quality of miscanthus stalks grown under different agroecological conditions of Serbia, Maksimovic et al. (2016 a, 2016b) concluded that growing conditions and applied agro-technical practices did not have a greater impact on the chemical composition of above-ground biomass, since during the plants maturation the highest percentage of nutrients is transferred to rhizomes.

In the two-year average, the average cellulose content of stalks was $32.11 \%$. On average, cellulose content was by $0.12 \%$ (by $0.37 \%$ ) higher in the second year of the experiment, i.e. 2019. However, the studied factors meteorological conditions and nitrogen nutrition did not have a statistically significant effect on cellulose synthesis in plants (Table 2, Figure 3b).

\section{Correlations of tested traits}

Correlations of tested traits are presented in Table 3. The yield of dry stalks per hectare was positively correlated with number of stalks in tassel period $\left(\mathrm{r}=0.85^{*}\right)$, with temperatures $\left(\mathrm{r}=0.74^{*}\right)$, plant height $\left(\mathrm{r}=0.70^{*}\right)$, cellulose content $\left(\mathrm{r}=0.66^{*}\right)$, with number of stalks in tiller $\left(\mathrm{r}=0.54^{*}\right)$ and a negatively correlated with precipitation amounts $\left(\mathrm{r}=0.74^{*}\right)$, (Table 3$)$. 
Table 3. Correlations of tested traits

\begin{tabular}{|c|c|c|c|c|c|c|c|c|}
\hline Variable & NoSTL & PHT & NoLP & NoST & DYP & $\mathrm{CC}$ & $\mathbf{P}^{1}$ & $\mathbf{T}^{2}$ \\
\hline $\begin{array}{l}\text { Number of stalks in } \\
\text { tiller-NoSTL }\end{array}$ & - & $0.45^{\mathrm{ns}}$ & $0.43^{\mathrm{ns}}$ & $0.75^{*}$ & $0.54^{*}$ & $0.16^{\mathrm{ns}}$ & $-0.07^{\mathrm{ns}}$ & $0.07^{\mathrm{ns}}$ \\
\hline $\begin{array}{l}\text { Plant height in tassel - } \\
\text { PHT }\end{array}$ & $0.45^{\mathrm{ns}}$ & - & $0.79^{*}$ & $0.81^{*}$ & $0.70^{*}$ & $0.39^{\mathrm{ns}}$ & $-0.56^{*}$ & $0.56^{*}$ \\
\hline $\begin{array}{l}\text { Number of leaves per } \\
\text { plant in tasseling - } \\
\text { NoLP }\end{array}$ & $0.43^{\text {ns }}$ & $0.79^{*}$ & - & $0.59^{*}$ & $0.39^{\text {ns }}$ & $-0.35^{\text {ns }}$ & $-0.23^{\mathrm{ns}}$ & $0.23^{\text {ns }}$ \\
\hline $\begin{array}{l}\text { Number of stalks in } \\
\text { tassel - NoST }\end{array}$ & $0.75^{*}$ & $0.81^{* *}$ & $0.59^{*}$ & - & $0.85^{* *}$ & $0.55^{*}$ & $-0.65^{*}$ & $0.63^{*}$ \\
\hline $\begin{array}{l}\text { Dry yield per plants - } \\
\text { DYP }\end{array}$ & $0.54^{*}$ & $0.70^{*}$ & $0.39^{\mathrm{ns}}$ & $0.85^{* *}$ & - & $0.66^{*}$ & -0.74 & $0.74 *$ \\
\hline Cellulose content - CC & $0.16^{\mathrm{ns}}$ & $0.39^{\mathrm{ns}}$ & $0.15^{\mathrm{ns}}$ & $0.55^{*}$ & $0.66^{*}$ & - & $-0.93^{* *}$ & $0.93^{* * *}$ \\
\hline
\end{tabular}

The cellulose content, plant height and number leaves per stalk were positively correlated with monthly temperatures and negatively correlated with precipitation amounts (Table 3).

Miscanthus (Miscanthus $\times$ giganteus Greef et Deuter) is a promising candidate for bio-energy purposes as it displays a number of positive characters, such as perenniality, high yield potential, low nutrient requirements, soil carbon sequestration and other ecosystem services (Anderson-Teixeira et al., 2009; Larsen et al., 2013). Nutrient requirements play a fundamental role on the sustainability of energy crops since fertilization has a great impact on GHG emissions (Davis et al., 2013). In fact, the production of nitrogen fertilizers is a particularly high energy demanding process, and gaseous emissions (e.g. $\mathrm{N}_{2} \mathrm{O}$ ) following its application have significant environmental impacts (Crutzen et al., 2008).

Fertilization has a great impact on GHG emissions and crop nutrient requirements play an important role on the sustainability of cropping systems. In the case of bio-energy production, low concentration of nutrients in the biomass is also required for specific conversion processes (e.g. combustion) (Roncucci et al., 2014). Keeping the nitrogen fertilization rate the lowest possible can have beneficial consequences on biomass quality. However, the variability in the pedo-climatic conditions among sites may mask the effect of crop managements on nutrient concentrations (Lewandowski et al., 2000). 


\section{CONCLUSIONS}

Based on the results of studied morphological and productive features of miscanthus in different and meteorological specific years, the following can be concluded:

-Miscanthus is a perennial plant. After the second or third year, depending on weather conditions, forms a stalk yield that covers production costs;

-This research have shown that seven years old miscanthus crops, planted on chernozem, can thrive under variable water regimes during the growing season. Therefore, in 2018, which was a year with variable precipitation amounts, satisfactory dry stalk yield was achieved;

-The average two-year yield of dry miscanthus stalks was $32.02 \mathrm{~kg} \mathrm{ha}^{-1}$ in the control and $33.37 \mathrm{~kg} \mathrm{ha}^{-1}$ in the variant with nitrogen fertilization. Yield differences indicate that weather conditions and nitrogen fertilizers had a statistically significant effect on yield levels;

-The studied miscanthus population has high genetic potential for biomass yield. High commercial biomass yields can be obtained under favorable water conditions (irrigation during critical water periods);

-Meteorological conditions and nitrogen fertilization did not affect the cellulose content of the stalks.

\section{ACKNOWLEDGEMENTS}

Research was supported by the Ministry of Education, Science and Technological Development of the Republic of Serbia (agreement number 45103-68/2020-14/200032 and 200045) and bilateral project (Montenegro-Serbia; 2019-2020): Alternative cereals and oil crops as a source of healthcare food and an important raw material for the production of biofuel.

\section{REFERENCES}

Acikel, H., (2011): The use of Miscanthus x giganteus as a plant fiber in concrete production. Scientific Research and Essays, 6 (13): 2660-2667.

Anderson-Teixeira KJ, Davis SC, Masters MD, Delucia EH (2009) Changes in soil organic carbon under biofuel crops. Global Change Biology Bioenergy, 1: 75-96.

Clifton-Brown, J.C., Lewandowski, I., Anderson, B., Basch, G., Dudley, G.C., Kjeldsen, J.B., Jørgensen U., Mortensen, J.V., Riche, A., Schwarz, K.U., Tayebi, K., Teixwira, F. (2001): Performance of 15 Miscanthus genotypes at five sites in Europe. Agronomy Journal. 93: 1013-1019.

Clifton Brown, J.C., Lewandowski, I., Bangerth, F., Jones, M.B. (2002): Comparative responses to water stress in stay green, rapid and slow senescing genotypes of the biomass crop, Miscanthus. 42NewPhytologist Symposium, Lake Tahoe, CA.

Crutzen, P.J., Mosier, A.R., Smith, K.A., Winiwarter, W. (2008): $\mathrm{N}_{2} \mathrm{O}$ release from agro-biofuel production negates global warming reduction by replacing fossil fuels. Atmospheric Chemistry and Physics, 8: 389- 395.

Davis, S.C., Boddey, R.M., Alves, B.J.R. (2013) Management swing potential for bioenergy crops. Global Change Biology Bioenergy, 5: 623- 638.

Djuric, N., Glamoclija, Đ. (2017): Introduction of mischantus in agricultural production in Serbia and the potential for using biomass for obtaining alternative fuels. Thematic Proceedings; 453-470. International Scientific Conference, Sustainable 
agriculture and rural development in terms of the Republic of Serbia strategic goals realization within the Danube region - support programs for the improvement of agricultural and rural development.

Đurić, N., Popović, V., Tabaković, M., Ćurović, M., Jovović, Z., Mladenović Glamočlija, M., Rakašćan, N., Glamočlija, Đ. (2019): Morphological and productive properties of miscanthus in a variable water regime. Journal of PKB Agroeconomic, Belgrade. 25, 1-2:

Dželetović, Ž., N. Mihajlović, Đ. Glamočlija, G. Dražići S. Đorđević (2009): Harvesting and storage Miscanthus $\times$ giganteus Greef et Deu. Agricultural Machinery. 34 (3): 9-16. UDK: 631.147, 633.2.

Dželetović, Ž., I. Živanović, R. Pivić and J. Maksimović (2013): Water supply and biomass production Miscanthus $\times$ giganteus Greef et Deu. Proceedings, 435-450. The 1st International Congress on Soil Science, XIII National Congress in Soil Science, Soil-Water-Plant, Belgrade, Serbia, 23-26.09.2013.

Dželetović, Ž. S and Đ. N. Glamočlija (2015): Effect of nitrogen on the distribution of biomass and element composition of the root system of Miscanthus $\times$ giganteus. Archives of Biological Sciences (Belgrade), 67, 2: 547-560. DOI: 10.2298/ABS141010017D.

Fowler, P.A., McLauchlin, A.R., Hall, L.M. (2003): The potential industrial uses of forage grasses including miscanthus. BioComposites Centre, University of Wales, Bangor, 1-37.

Glamočlija, Đ., N. Đurić, M. Spasić (2018): The influence of agro-ecological conditions on the production properties of miscanthus. $8^{\text {th }}$ International Symposium on Natural Resources Managment, 173-178. 19.09.2019. Megatrend University, Faculty of Managment. Zaječar, Republic of Serbia.

Gonzalez-Dugo, V., Durand, J.-L., Gastal, F. (2010). Water deficit and nitrogen nutrition of crops. A review. Agron. Sustain. Dev., 30: 529-544; DOI: 10.1051/agro/2009059

Ikanović, J., Popović, V., Janković, S., Rakić, S., Drazić, G., Živanović, Lj., Kolarić, Lj., Lakić, Ž. (2015): Production of biomass of miscanthus cultivated on degraded soil. Journal of Institute PKB Agroekonomik, Belgrade, Serbia. 20, 1-2: 115-123.

Larsen S, Jørgensen U, Kjeldsen J, Lærke P (2013): Long-term miscanthus yields influenced by location, genotype, row distance, fertilization and harvest season. Bioenergy Research, 7: 620-635.

Lewandowski, I., Clifton-Brown, J.C., Scurlock, J.M.O., Huisman, W. (2000). Miscanthus: European experience with a novel energy crop. Biomass and Bioenergy, 19: 209-227. DOI: 10.1016/S0961-9534(00)00032-5.

Lewandowski, I. and Heinz, A. (2003): Delayed harvest of miscanthus - influences on biomass quantity and quality and environmental impacts of energy production. European Journal of Agronomy, 19, 1: 45-63. DOI: 10.1016/S11610301(02)00018-7.

Maksimović, J., Dželetović, Ž., Dinić, Z., Stanojković- Sebić, A., Pivić, R. (2016a): Quality analysis of the Miscanthus $x$ giganteus biomass cultivated in agroecological conditions of the R. of Serbia. VII Scien. Agriculture Symposium, Agrosym, Jahorina, 2008-2014. DOI: 10.7251/AGRENG1607300.

Maksimović, J., Pivić, R., Stanojković-Sebić, A., Vučić-Kišgeci, M., Kresović, B., Dinić, Z., Glamočlija, Đ. (2016b): Planting density impact on weed infestation and the yield of Miscanthus grown on two soil types. Plant, Soil and Environment, 62(8): 384-388. DOI: 10.17221/234/2016-PSE. 
Monti, A., Zatta A. (2009): Root distribution and soil moisture retrieval in perennial and annual energy crops in Northern Italy. Agr. Ecosyst. Environ. 132, 252-259. DOI: 10.1016/j.agee.2009.04.007.

Roncucci N., Nassi O Di Nasso N., Tozzini C., Bonari E., Ragaglini G. (2014). Miscanthus $\times$ giganteus nutrient concentrations and uptakes in autumn and winter harvests as influenced by soil texture, irrigation and nitrogen fertilization in the Mediterranean. Bioenergy. doi.org/10.1111/gcbb.12209

Živanović, Lj., Ikanović, J., Popović, V., Simić, D., Kolarić, Lj., Bojović, R., Stevanović, P. (2014): Effect of planting density and supplemental nitrogen nutrition on the productivity of miscanthus. Romanian Agricultural Research, No. 31:291-298; DII 2067-5720 RAR 428. 